\title{
Late Atlantic Settlement in Southern Portugal \\ Results of an excavation of a Mesolithic shell midden by the River Sado
}

\author{
Lars Larsson
}

\begin{abstract}
The study of large settlement sites with graves from the Late Mesolithic has changed our conception of this period. In western Europe this kind of antiquity has long been known, and it is well represented in the coastal area of western Iberia. One settlement site - Poças de São Bento, near the River Sado in southern Portugal - has recently been excavated as part of a joint Swedish-Portuguese project. The results of the excavation give interesting perspectives on specific and general conditions in a broader geographical, chronological, and social context.
\end{abstract}

Lars Larsson, Institute of Archaeology, University of Lund, Sandgatan 1, S-223 50 Lund, Sweden.

The excavations of the Late Mesolithic settlement around an ancient lagoon at Skateholm in southern Scania helped to qualify our perception of the Late Mesolithic in a concrete way (Larsson 1984, 1988, $1989 \mathrm{a}, 1989 \mathrm{~b}, 1990)$. The combination of settlement sites and cemeteries gave grounds for a reinterpretation of the late huntergatherer societies. Investigations of cemeteries such as those at Skateholm and at Bøgebakken in eastern Jutland (Albrethsen \& Brinch Petersen 1977), as well as other burial places documented since then, in both Zealand (Brinch Petersen 1988) and Jutland (Hougaard Rasmussen 1990) have radically influenced our approach to Late Mesolithic societies in northern Europe. Previously, the generally held view was that these societies had a comparatively uncomplicated structure. No major difference was believed to exist between these societies and those which had preceded them during the Mesolithic.
The evidence of large cemeteries with complex burial practices not only increased our information about the society, but were also to have an effect of a more fundamental nature. A barrier to research of almost a mental nature had been broken through. Following the grave finds, the Late Mesolithic was perceived almost without reservation as a period of complex social structures (Price 1985), which were regarded in many cases as being equivalent in some respects to the contemporaneous Early Neolithic societies on the Continent. This also gave rise to a new approach to the transition between the Mesolithic and the Neolithic in south Scandinavia, which in several cases touched on the seemingly eternal question of Neolithization and the significance of the active or passive role of Mesolithic society in this change (Chapman 1981; Price 1985; Whittle 1985; Zvelebil \& Rowley-Conwy 1986; Hodder 1990). 


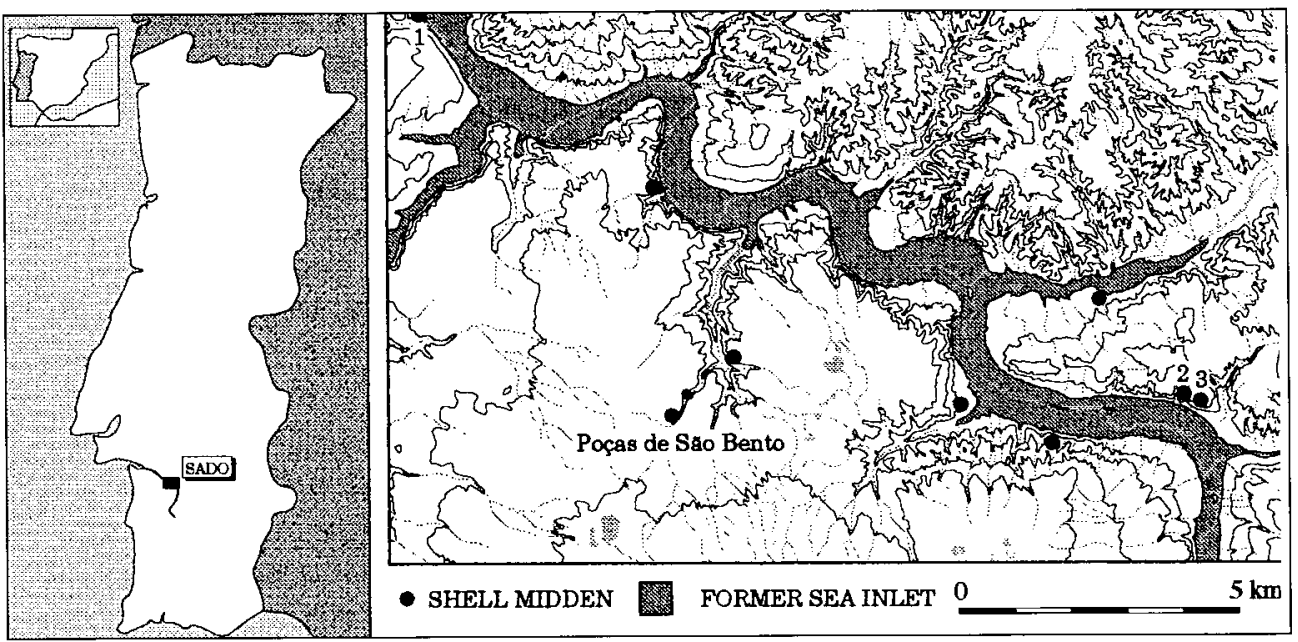

Fig. 1. The location of Poças de São Bento and other shell middens mentioned in the text along the River Sado. 1: Arapouco, 2: Romeiras and 3: Cabeço de Pez.

Although the regional significance of these finds has been recognized, we should not forget that the phenomenon of a combination of settlement and graves has a considerable geographical spread, including the Atlantic coast of western Europe. A study of settlement and burial in a western European perspective ought to incorporate the previously excavated cemeteries from the Late Mesolithic, such as those at Hoëdic and Téviec on islands south of Brittany (Pequart, Pequart, Boule \& Vallois 1937; Pequart \& Pequart 1954) and several sites in presentday Portugal (Roche 1972, 1989; Lubell et al. 1989).

If there should turn out to be similarities in the localization of the cemeteries, the next question is whether there are general features in coastal settlement which bridge geological and ecological differences, or if local conditions are of decisive significance for the form of settlement and mortuary practices. When the problem is formulated in this way, one has to try to acquire detailed knowledge of the find localities that are known along the Atlantic coast of Europe and their specific structure.
A comparison between southern Portugal and southern Scandinavia may seem farfetched, but one must bear in mind that temperatures were a few degrees higher in Scandinavia than they are today. The climate of south-west Europe appears to have been slightly cooler during this period than it is today (Mateus 1992). The geographical difference remains, but the ecological difference was thus much smaller than it is today. One can, if one chooses, see Skateholm as a northern offshoot of the coastal settlement of western Europe and the southern Portuguese sites as the southern outpost. An invitation to collaborate and exchange knowledge was the starting point for the excavation of a find locality in southern Portugal.

\section{THE POÇAS DE SÃO BENTO SITE}

The excavations in southern Portugal, which were carried on for three seasons 1986-1988, contributed interesting perspectives on coastal settlement in general and shell midden in particular. The investigation area is situated some $100 \mathrm{~km}$ south-east of Lisbon, in the valley of the River Sado. The lower course of this river comprises a broad delta and a 
valley cut deep through sand and clay. In the latter section there is a group of shell middens which appear today to be inland sites, since they are about $30 \mathrm{~km}$ upstream from the estuary (Fig. 1).

The higher level of the oceans in Late Atlantic time meant that the present river valley was transformed into a very narrow inlet reaching deep into the country. Tides still affect the course of the river current more than $20 \mathrm{~km}$ from the estuary, but in Atlantic time this effect was even stronger. The supply of fresh water from what was then a much shorter river was combined with an increased inflow of salt water through the effect of the tides. This helped to maintain a high acid level and a continuous supply of nutrients, which favoured several aquatic species. The occurrence of molluscs in large quantities and fishbones and remains of shellfish at the find spots along the river show that the water roughly $30 \mathrm{~km}$ up the valley had a salt content on a par with that found at the present delta of the River Sado. This unusually productive environment is the most important reason for the accumulation of shell middens. The fact that the level of the valley floor was almost unchanged along a long stretch meant that the tides had a noticeable effect on the shape of the inlet. At ebb tide a section of the valley floor several kilometres long was partly dry but covered with a nutrient-rich layer of mud, in which molluscs and crabs found shelter until the next high tide came in.

The investigation area of the Sado Project comprises a 10-kilometre stretch of the river valley. The valley here is between 500 and $800 \mathrm{~m}$ wide, and the sides of the valley vary in shape from gentle slopes to steep banks. The difference in level between the valley floor and the surrounding terrain is up to $50 \mathrm{~m}$. About ten shell middens are known in the area, five of which have previously been investigated in excavations on varying scales (Morais Arnaud 1986, 1989; Gonzalez Morales \& Morais Arnaud 1990). The shell

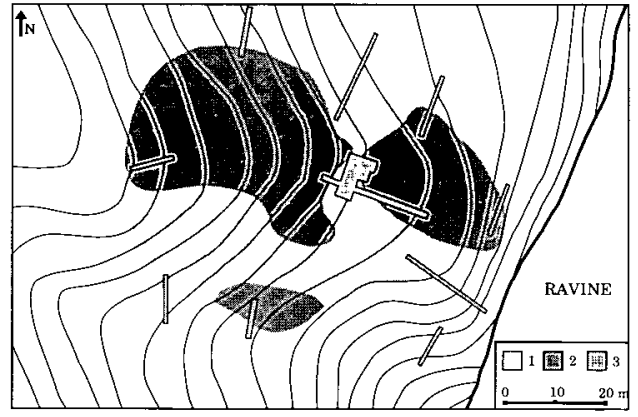

Fig. 2. Plan of the excavated area. Symbols: I the extent of the settlement site; 2 the extent of the shell-bearing layers; 3 excavated areas. The trench in the middle comprises the excavations in 1987-1988. The levels are marked by contours every half-metre.

middens vary in size from about 50 square metres to around 8000 square metres. With a few exceptions, they are situated on the top of the valley slopes.

One shell midden - Poças de São Bento - is in a location that differs significantly from that of the others, since it is about $3 \mathrm{~km}$ from the valley. It nevertheless has occupation layers with a high content of shells. In addition, the site is of considerable size, some 4000 square kilometres. Poças de São Bento lies on a rise in an area of sand-dunes. Immediately to the east of the site there is a pronounced ravine leading down to the river (Fig. 4). The ravine is fed with water from springs, even during the summer. When it rains in winter, the bottom of the ravine is filled with a proper watercourse. From the site of the shell midden down to the bottom of the river valley the difference in height is about $70 \mathrm{~m}$. Despite a richer supply of water, no part of the lagoon came closer to the habitation site than about $2 \mathrm{~km}$.

An excavation of this site was undertaken at the end of the 1950s under the leadership of Professor M. Heleno. The investigation consisted of digging several metre-wide test trenches, the same approach as was used for 
the other shell middens investigated in the Sado valley at the same time. The aims of the excavation were to define the area of the shell midden and to search for remains of burials. Graves were found in one of the trenches, which led to the excavation of a wider area. A total of twelve graves were then found. Unfortunately, the majority of the documentation material has been lost. The location of the site and interesting results from earlier excavations were the reason for undertaking a new excavation. This was carried out in 1986-88 as a joint Swedish-Portuguese project, with archaeologists and students from both countries taking part.

\section{STRATIGRAPHY AND FEATURES}

The work in the first season was more or less a trial excavation. A large number of probes were made to give an idea of the stratigraphy of the settlement site. These showed that it comprised at least three distinguishable accumulations of shells of varying size (Fig. 2). Areas of varying size lacking shells were also found within these accumulations. Since the probes were taken at five-metre intervals in the central part of the site but more widely spread on the periphery, it is possible that there are further divisions of the shell-bearing layers. The work of the following two seasons (1987-88) was concentrated on excavating a continuous area of more than 20 square metres. This lay next to the large trench of 12 square metres in which the previous excavation in the late 1950 s had discovered graves.

The new excavations gave a good idea of the form of the site. It turned out that the shell-bearing layers in this shell midden which had been distinguished by the probes were not a continuous formation (Fig. 5). The layers of shells had an extent of just a few square metres and can best be described as accumulations of shells up to a metre thick on the original ground surface. The highly uneven top surface of the shell-layer gives the impression that these piles of refuse arose as a result of a short-term accumulation

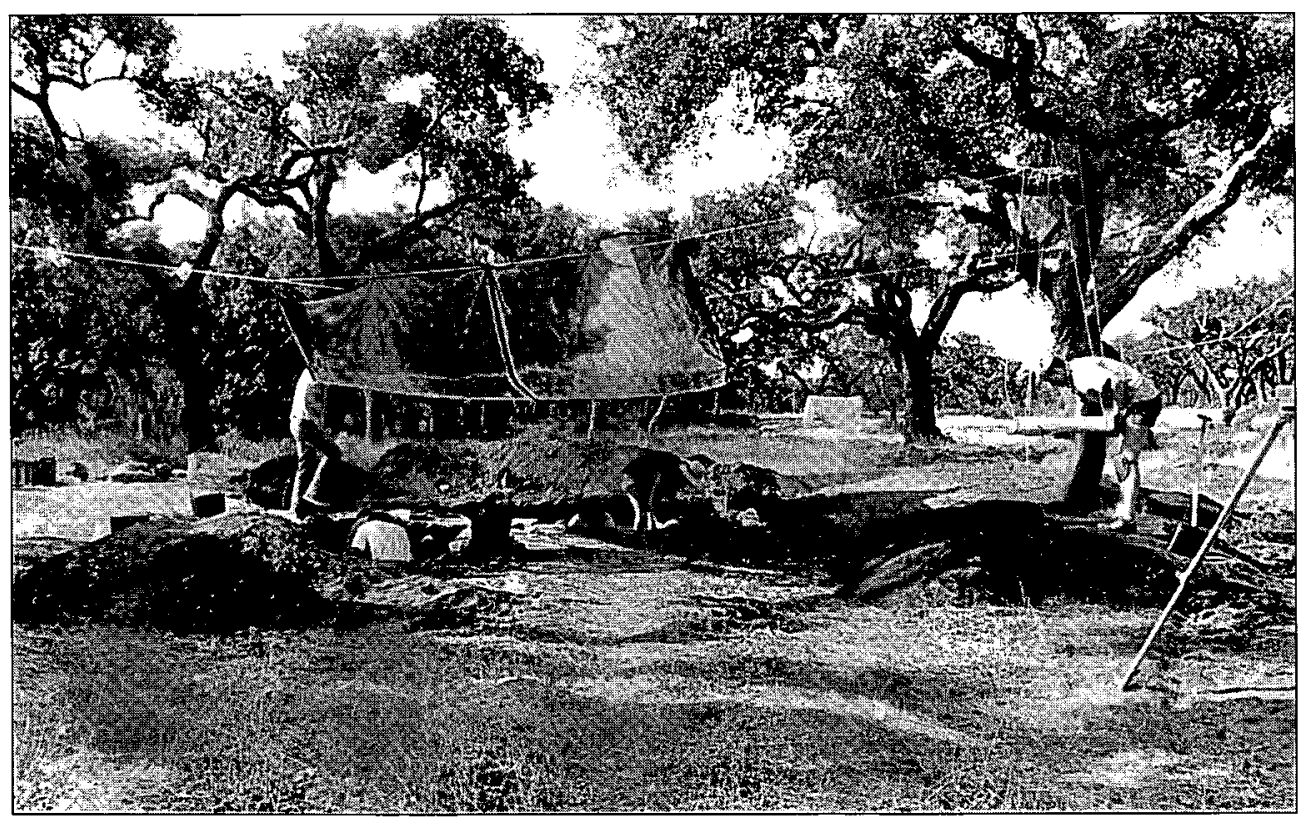

Fig. 3. The excavation area is located in an area with a thin cover of cork oak. 


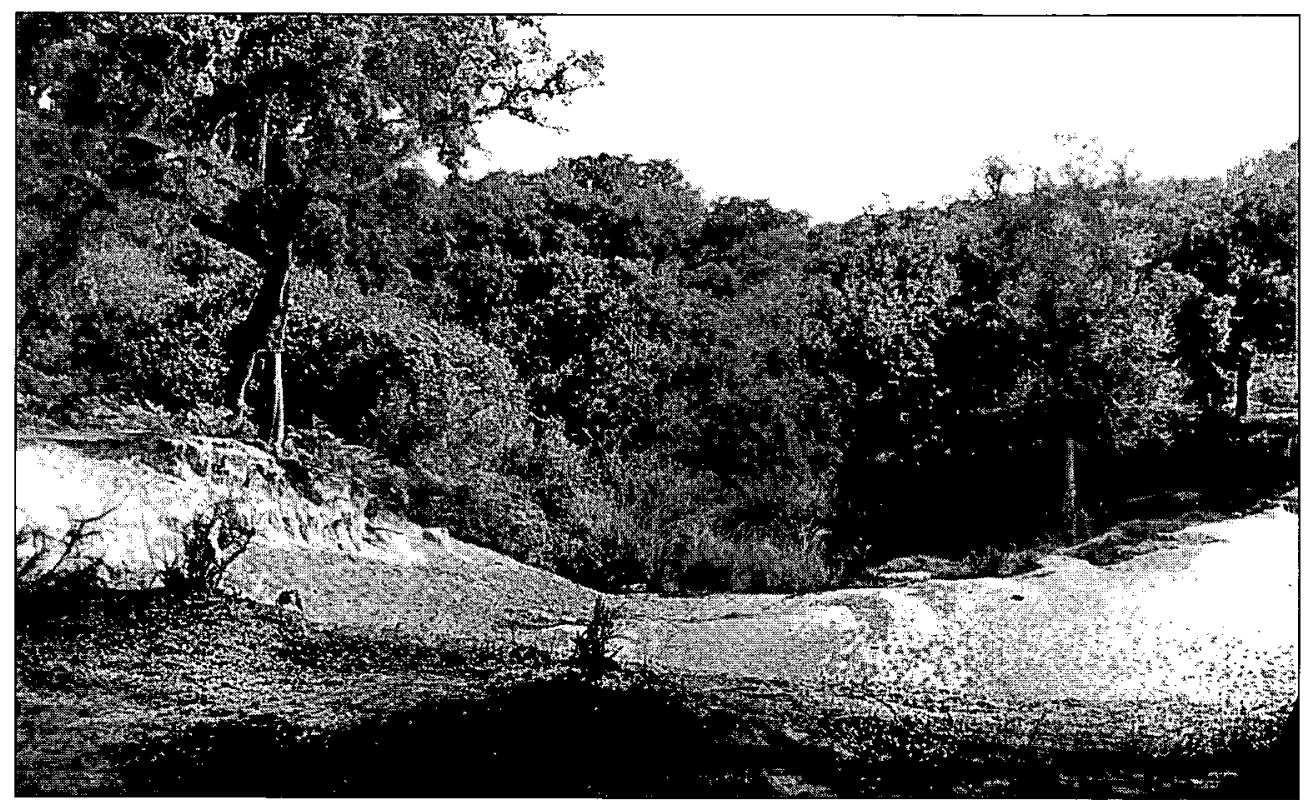

Fig. 4. The ravine a few hundred metres from the site

of shells (Fig. 6). Refuse from a few days' consumption of mussels may have been collected in baskets and then emptied in a place designated for the purpose. The results of the probes show a similar striking variation in the thickness of the shell-layers in other parts of

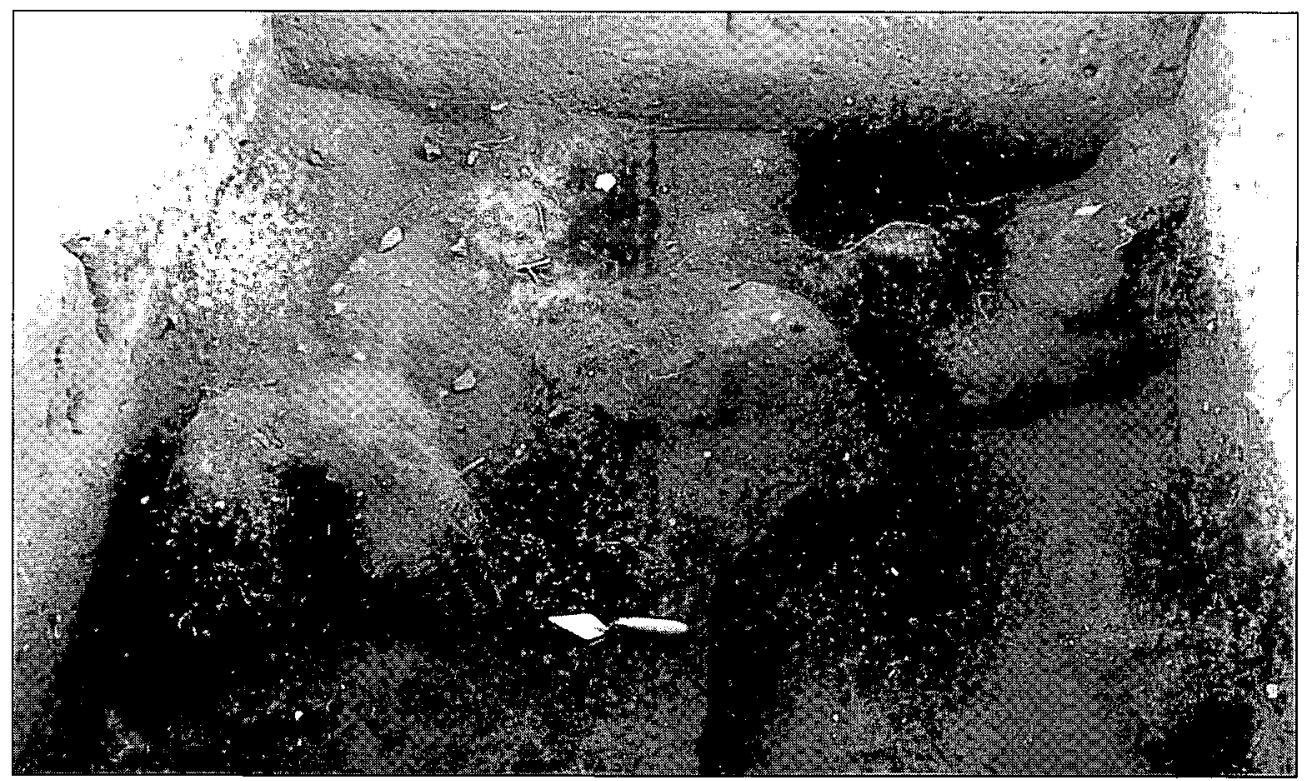

Fig. 5. The surface of the shell-layer showed considerable variation. 


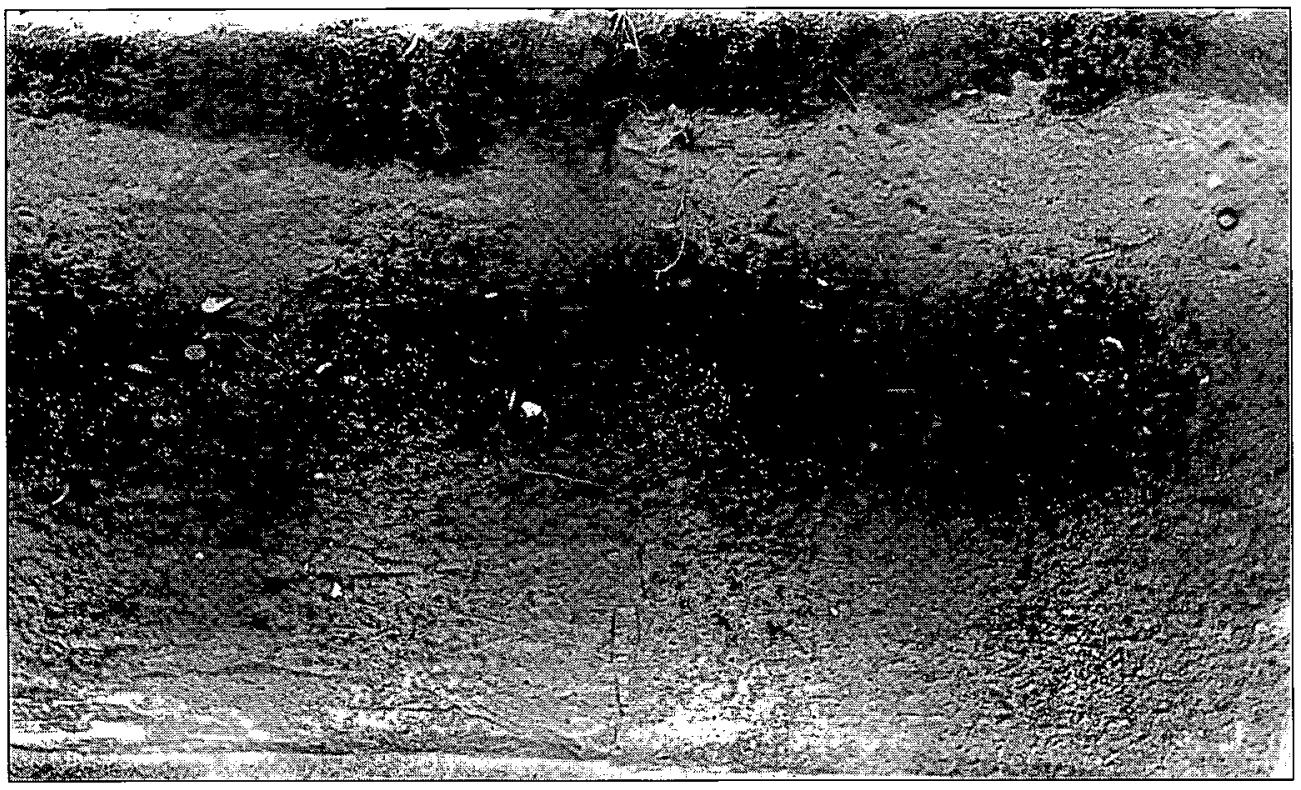

Fig. 6. Cross-section of the settlement site. The topsoil is marked by a damp and hence dark-coloured layer. Under this is a lighter-coloured layer with finds from the Neolithic settlement. Under that is a black occupation layer and under that the shell-bearing layers. Note their varying thickness. The lightcoloured sand can be seen at the bottom.

the site.

The complicated stratigraphy is seen in a section through the excavated area, on to which are projected the finds from a 0.2 metre wide slice behind the section (Fig. 7). In this area the shell-less occupation layer was of limited size. Layers with greater or lesser admixtures of shells dominated (see plan, fig. 8). The majority of the bone finds were unearthed in the shell-bearing layers. It is not possible, however, to discern any clear correlation between the distribution of stone artefacts and any particular layer. The number of artefacts decreases the deeper one comes.

This sequence, however, should not be assumed to apply to the remaining parts of the site. In other places there was a considerable proportion of artefacts in the layers that were rich in shells. The number of bones in the shell-layers varied significantly from al- most total absence in some occupation layers to a greater proportion in others. The occurrence of humus also varied considerably. Normally there are greater amounts in the upper levels of the shell-bearing layers.

Shells of Cerastoderma edule (common cockle) and Scrobicularia plana (peppery furrow-shell) were overwhelmingly predominant in the refuse, although other species did occur, such as Neritina fluviatilus and Hinia reticulata. In some cases, concentrations of shells from a particular mollusc hinted that the remains of a single shellgathering were assembled in one place.

Between the accumulations of shells and partly over them there was a sooty occupation layer containing a large amount of stone tools and refuse from tool-making. Remains of hearths in the form of fire-cracked stones and burnt clay were documented in the occupation layers. The clay in these features 


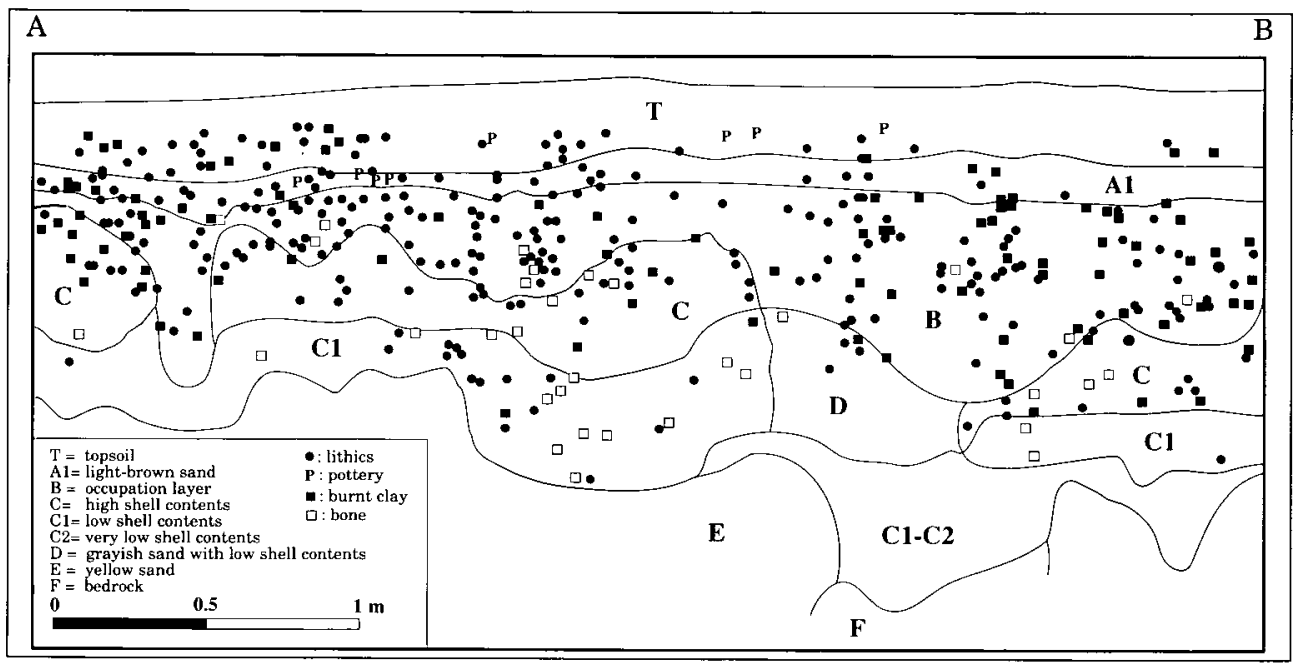

Fig. 7. Section through the investigation area (see fig. 8:A-B), on to which are projected finds from a 0.2 m thick slice behind it.

may possibly derive from some kind of oven. One of the pits under the find-bearing layers contained large quantities of red ochre. There were no remains or colouring to suggest that any person was buried in the pit. Small pieces of red ochre were also found in the settlement site layers. The analysed charcoal samples mainly consist of stone pine.

In a few cases it was clear that the molluscs at the bottom of the assemblage had been subjected to heat. The accumulation of charcoal shows that this heating was done on the site. The limited spread of heated shells shows that the fireplaces were small. These then served as fixed points for the accumulation of shell remains. In a few cases a shellfilled pit was the base for an accumulation of shells.

The form of the shell-bearing layers differs noticeably from conditions in other find spots, such as the Danish shell middens where there is a stratigraphically complex accumulation of shell-layers and settlement remains with an almost horizontal extent (Andersen \& Johansen 1987; Andersen 1991; Larsson 1993). This difference, however, may be due in part to the special topographical conditions, the location of Poças de São Bento on a sand-dune where accumulations of waste could be preserved by being covered with sand. But this is scarcely the whole explanation. The differences in the spatial utilization of the site, the relation between activities and refuse, and the use of the site both in the perspective of an annual cycle and in a longer temporal perspective of generations or centuries, also had an effect on the way the layers of shells accumulated.

The features that appear of particular interest are the colourings left by stout post structures. It was possible to document occasional post-holes associated with a late settlement on the site (Fig. 7). Most of the colourings left by posts, however, were documented in the layers under the shells (Fig. 8). The structure or structures built here were thus used during a phase preceding the accumulation of shells. This is also corroborated by the fact that the post-holes rarely contain any shells. The holes had a diameter of between 10 and $30 \mathrm{~cm}$ and a depth reaching a maximum of $60 \mathrm{~cm}$. This suggests that 
certain holes contained really thick posts. The excavated area is much too small, however, to allow us to distinguish any clear pattern in these post-holes. Some post-holes suggest that the structure was substantial, perhaps serving as a frame for one or more houses. Other functions may also be suggested, such as drying frames. There were also distinct stains left by trees or bushes which had grown on the site before it was used as a habitation site, and in a few cases the distinction between tree roots and post-holes is uncertain.

A total of twelve graves had been found by the earlier excavation in the lower part of the shell-layer or in the sand under the shelllayers (Fig. 8). It is evident from the stratigraphy that the graves were dug both before shells were accumulated and in conjunction with the deposition of shells. Since there are several assemblages of shells, the majority of the activities may have been confined to one part of the site, while the dead were buried in a different part. The trial excavation of 1986 uncovered a skull which can be associated with a previously documented collection of human bones (Fig. 8, grave XI). The stratigraphy clearly shows that the deceased was placed in a shallow pit which had been dug down from an almost shell-free sand surface, since the filling contained only a small amount of shells.

From the limited documentation that survives, we know that parts of the buried bodies were missing, which may be due in part to poor preservation conditions and later digging. Despite this, it was evident that the deceased was buried in crouched position. No grave goods which can be certainly associated with the burial were found. A few beads, in the form of perforated shells, found close to a skeleton may have been part of the dead person's ornaments. Stones were found over a couple of skeletons, perhaps the remains of a grave structure.

Yet another skeleton, but lacking a skull and much of the trunk, probably on account of varying preservation conditions, was found by the new excavations, but at a distance of a few metres from the previously documented concentration of graves (Fig. 8) Unlike the latter, the newly discovered grave was placed directly above the surface of the shell-layer, which means that it cannot be assumed to be of the same age as the Mesolithic settlement. The fact that no other skeletons were discovered in the newly excavated area alongside the assemblage of graves suggests that most of the graves were dug in a limited part of the site.

\section{THE FINDS}

The raw material for tool manufacture varied. Flint - often of low quality and in small pieces - was preferred, but basalt, quartz, and rock crystal were also used. Most of the raw material is not locally available. The artefact inventory is limited, with microblades (Fig. 9: 11-12) made from small one-sided cores (Fig. 9:13) being the most common form. Either the microblades were used directly or they were reshaped into microliths, the most common form being the narrow segment, but triangular and narrow trapezoid shapes also occur (Fig. 9:1-8). These microlith forms and the microburin technique show significant similarities to those found in the latter part of the southern Scandinavian Maglemose culture.

Few other stone tools are attested. Some larger debitages were used directly as cutting tools, judging by the traces of wear. A highly limited number of scrapers and burins were found (Fig. 9:16). Long, narrow pieces of slate were cut (Fig. 9:14) and shaped into tools with a round-oval or pointed-oval section (Fig. 9:15). Some fragments have a form resembling that of a knife blade. The function of these tools, which occur in varying sizes, is difficult to interpret.

In relation to the number of bone finds, the number of tools made of bone or antler is very small. Some bone points and a few percussion sticks of short antler tines were 


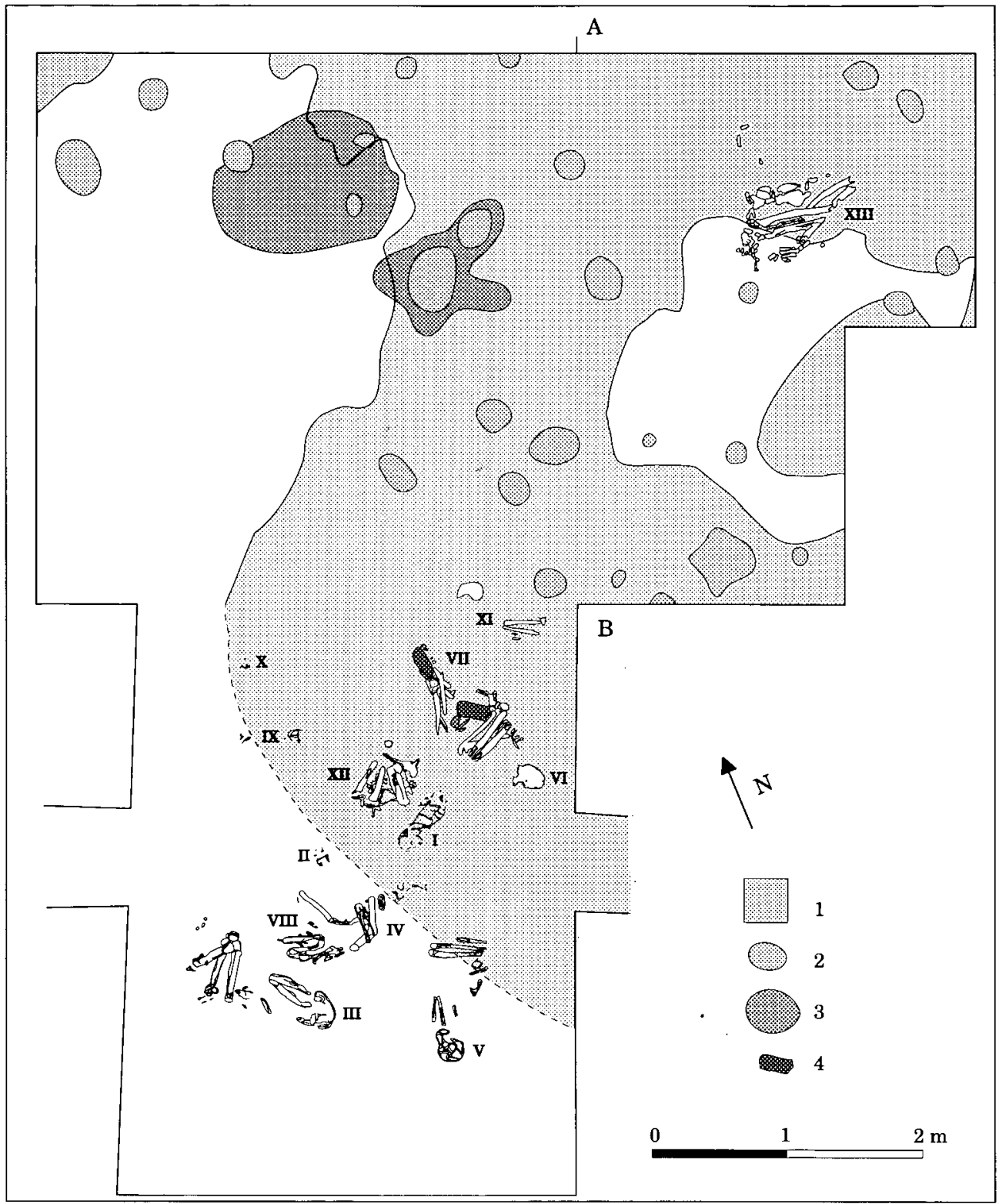

Fig. 8. Compilation of areas excavated in the late 1950s and in the 1980s. Symbols: I the extent of the shell-layers; 2 colourings left by post-holes; 3 pits; 4 large stones.

found. On the other hand, there are finds of perforated fish vertebrae used for decoration. Bored holes in some mussel shells suggest that ornaments were also made from that material.
No axe-like tools were found. This in itself need not mean that the people did not master the art of working wood, but there are no splitting tools of bone or antler which could have been used instead of stone axes. 
Wood crafts were pursued in a way that differs completely from that found in the Nordic area. Some fishbones suggest that fishing was carried on in the open sea, which suggests that there may in fact have been a need for wooden vessels.

Of particular interest are the many finds of burnt clay, although no pottery has been found except in the topmost layer of the site. Some pieces have smooth surfaces, while others bear impressions of branches, which suggests that they were part of a level surface and were used as daub. Yet there were also small collections of lumps of clay beside pits and post-holes, which were difficult to interpret. The only artefacts of burnt clay in a clearly Mesolithic context are a couple of round, perforated beads (Fig. 9:17-18). These are evidence either of distant trade contacts or of a regional knowledge of ceramic products.

\section{PHYSICAL ENVIRONMENT AND SETTLEMENT PATTERN}

The lack of lakes and well-preserved fluvial sedimentation in the area means that the closest available site for pollen analysis was in a lagoon near the coast, about $20 \mathrm{~km}$ from the present site (Mateus 1985, 1992). The pollen spectrum for the Late Mesolithic shows a predominance of pine and oak, with some olive trees and a rich understorey consisting of bushes - in other words, vegetation not very different from today's. The composition of the vegetation suggests that the climate was somewhat cooler than it is today.

Finds of animal bones give us insight into the varied way the society used its surroundings. The predominant mammals are species such as red deer and wild boar, a situation that is generally known for the whole of Europe. Evidence of aurochs and horse, along with numerous rabbit and hare bones, nevertheless shows that the hunting grounds around the site were covered with sparse forest and ample undergrowth.
Apart from the mussel shells, it is the fishbones and parts of crab claws which indicate that a significant part of the food was brought here from the narrow inlet. Among the fish there are several species of shark and skate as well as mackerel, meagre, black bream, and grey mullet. Although the water level was higher then, the distance from the inlet was just over two kilometres, with a difference in height of roughly 70 metres.

As we have seen, Poças de São Bento is only one of several shell middens around the former inlet. The others are located directly above the sides of the river valley with a good view of the former inlet, where rice fields today completely dominate the view. C14 datings indicate that some of the settlement sites were used roughly simultaneously (Fig. 10), and those which have been excavated show a combination of occupation layers and graves. However, the size of these settlement sites varies considerably, from about 50 to roughly 8000 square metres. In addition, the number of graves does not appear to be in any proportion to the size of the settlements. Small sites can contain many graves and big sites can have few graves. The amount of refuse, apart from shells, also differs greatly, as does the number of stone tools and refuse from tool making.

Cemeteries have been found at several Portuguese shell middens (Roche 1972, 1989). In the Sado area cemeteries have been documented at five excavated shell middens. The number of graves in relation to the size of the site reveals certain interesting aspects. Twenty-seven graves were investigated at the Cabeço de Pez site, which covers about 8000 square metres. At Romeiras, which is situated only a few hundred metres away and is separated from the large site by a smallish ravine (Fig. 1), twenty-two graves were investigated beneath a shell midden covering about fifty square metres. There is thus nothing in this and other examples from the valley of the river Sado to give a clear 


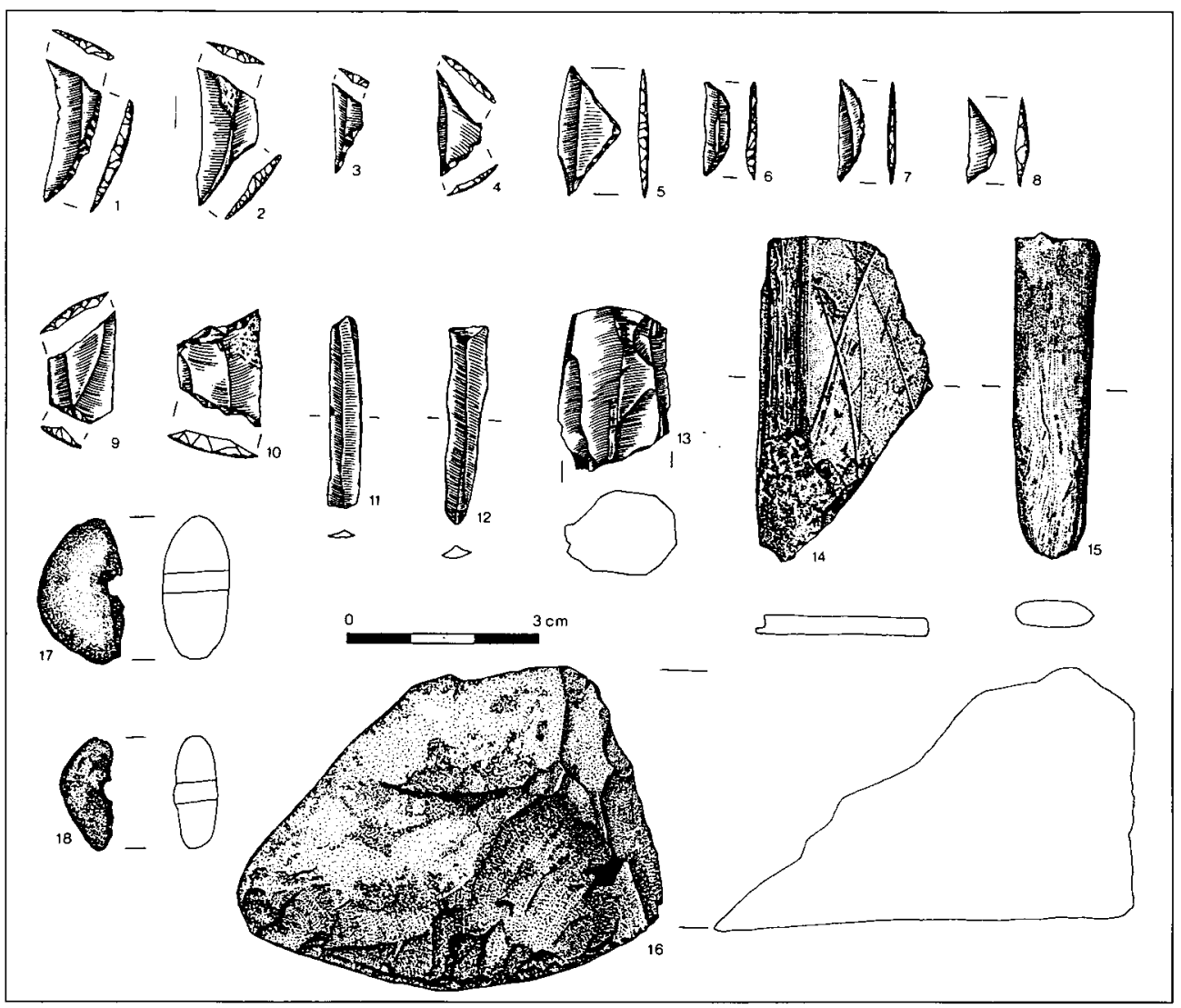

Fig. 9. Forms of tools from the settlement site: 2-4 narrow trapezes, 1, 5 triangle microlith; ; 6-8 segments; 9-10 broad trapezes; 11-12: microblades, 13: microblade core, 14: piece of slate with traces of cut furrows; 15 fragments of a slate knife, 16: stone scraper; 17-18 fragmentary beads of burnt clay. Drawings by Björn Nilsson.

indication of the existence of a distinct relationship between the number of graves and the size of the site. Also, the graves at these find locations occur in groups within a relatively limited area. Individual graves appear to be a comparatively rare phenomenon. In one case, Vale de Romeiras, a clear distribution of the graves can be distinguished: they were placed radially in a semicircle. This is a strong indicator that burial for a considerable period was carried out with a clear structural and organizational influence on the placing of the graves. This is in distinct contrast to the interpretation of similar sites as short-term camp sites with sporadically dug graves (Knutsson 1995).

Another aspect to be considered in the study of the settlement pattern is that only shell-bearing find spots have been noticed. The shells have made these places easy to discover - attention has been drawn to many of them by shepherds in the district. In conjunction with the excavation of Poças de São Bento we received information about shell finds on the ground surface a few hundred metres from the burial site. When the place was visited, a few square metres were strewn with remains of shells. Within a 
slightly larger area there were occasional debitages and tools. This suggests that there are settlement remains which were deposited during short periods of occupation. If there was settlement down on the shore of the inlet, then remains of it have probably been covered as a result of far-reaching erosion of the steep slopes of the river valley.

The distances between the shell middens vary from a few hundred metres to roughly five kilometres. The differences observed between the shell middens by the River Sado are probably due to their having been used as camp sites for varying lengths of time during an annual cycle by the hunter-gatherer societies, depending on the availability of various resources.

In relation to the other find spots, Poças de São Bento can be seen as a settlement site with an average number of graves, few bones from forest animals, but relatively many fishbones, copious remains of shellfish and molluscs, and plenty of refuse from tool making (Arnaud 1989). Poças de São Bento is thus not the settlement site with the least marine orientation, as the distance from the inlet might suggest; on the contrary, we see a distinct preference for marine food, with mussels, crabs, and salt-water fish. Why then is the site located so far from the lagoon? One explanation could be that other assets were of greater significance in the choice of settlement site. Today there are richly flowing springs a few hundred metres from the site which may also have existed in the Mesolithic. It cannot be ruled out that this important supply of fresh water played a major role for the location of the camp, especially during the dry summer. Other resources may have tempted people to settle here, such as vegetables, which are not preserved. Despite extensive flotation, no fruits or seeds could be identified.

The indications for the seasonal orientation of settlement are somewhat contradictory. Isotope analyses of a few sites located along the shores of the inlet suggest that mollusc collecting took place during the autumn and winter (Arnaud 1990). The occurrence of certain fish species, however, suggests summer activity (Arnaud 1985).

During the summer the lagoon was probably a suitable environment for a multitude of insects which would not only have been irritating to humans but also caused diseases. Malaria occurred here right into the 1970 s (Bruce-Chwatt \& de Zulueta 1980). This may have meant that people preferred to stay for as short a time as possible at certain times of the year, instead taking the food inland to prepare it in a place where they could escape the insects.

Naturally, we should not forget that the conceptual world in those days may have had other reasons for selecting a site, which may be difficult or impossible for modern man to understand.

Spatial analysis has over-valued ecological factors. A society constructs its own social geography which is associated with resource use, power structure, and social and symbolic strategies. If one judged only according to the significance of the ecological factors, one might conclude that in many respects Poças de São Bento is misplaced. For practical or social reasons, different groups within a habitation used different resources at different distances from the site. Here one can distinguish sedentary resources from mobile ones. By the former is meant fruit, seeds, and molluscs, and perhaps small game, while the latter refers to big game and certain kinds of fish. For the point of view of optimum use of an area, the site ought to have been located beside an easily accessible and almost constant resource - in this case the molluscs. Yet this is not the case. Transporting large quantities of such a low-calorie resource as mussels from the inlet, without first processing them, must have involved a direct loss of energy.

It is evident, despite the limited archaeological investigations in the Sado area, that burial was no casual, unpremeditated pheno- 


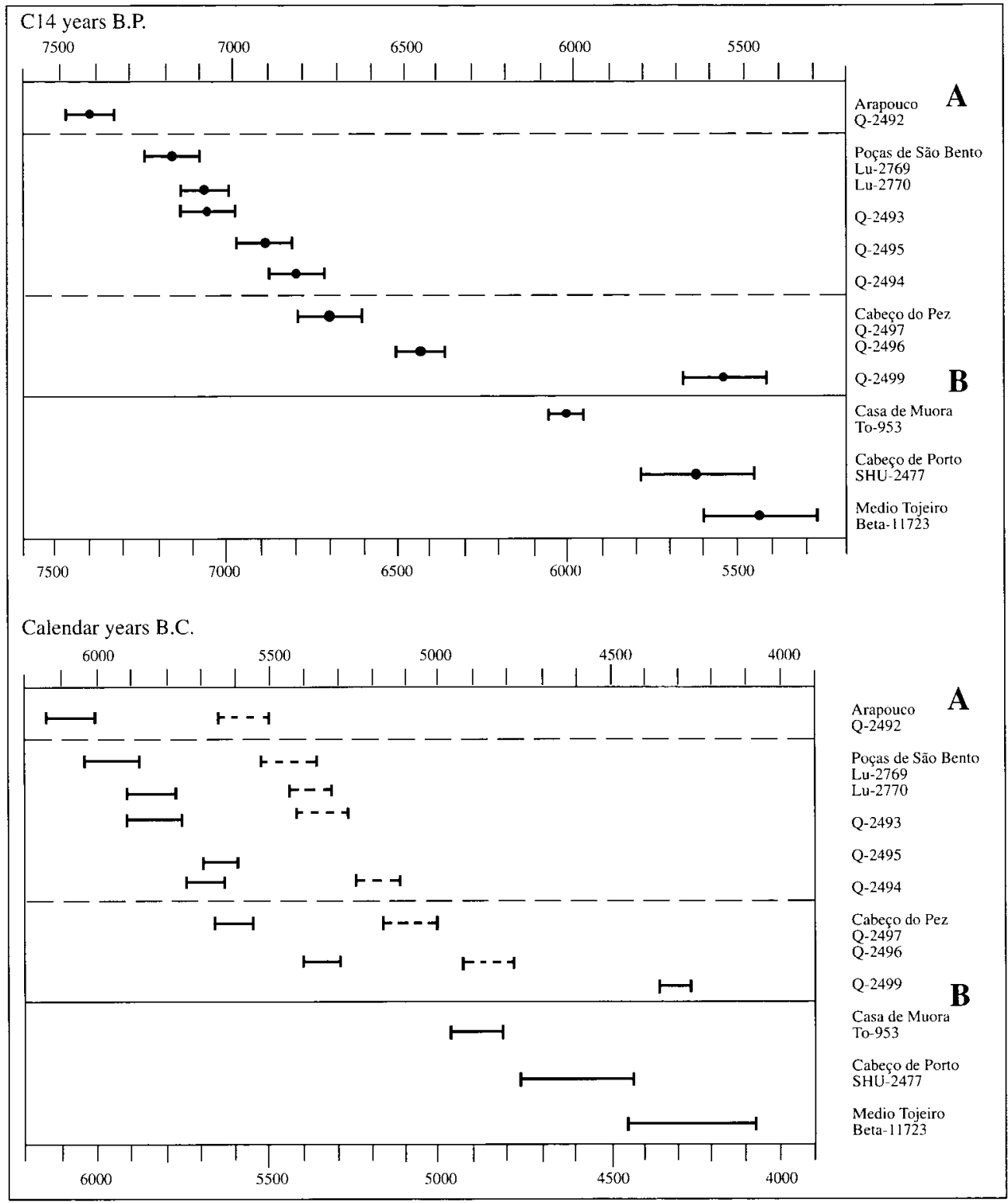

Fig. 10. C14 datings uncalibrated (above) and calibrated (below) from the settlement sites in the Sado area (A) and some of the oldest sites dated to the Cardial $(B)$. The values calculated for the apparent age of the estuarine shell, $360 \pm 36$ years (Zilhão 1993) are marked by a hatched line.

menon. Graves were grouped, occasionally with a distinct structure. If one accepts recent revisionist analyses of hunter-gatherer societies, one could see this as a clear marking of a structured settlement pattern in which the known settlement sites were part of a sedentary utilization pattern (Knutsson 1995).

When trying to understand the settlement 
pattern, it is important to consider the local conditions. These habitation sites are located in an inland area where the former narrow inlet gave the area a special character. This first came about as a result of rises in sea level in Late Atlantic time. The surrounding landscape was relatively sparsely populated. Only for a few centuries was there a highyield environment allowing opportunities for denser settlement. Such a change probably gave rise to increased contacts between people, with consequences of both a positive and a negative kind. Various forms of protective mechanisms connected with the social and ideological sphere must have been developed. The role of the marine environment, but also its inconstancy, may have been important factors in the conceptual world.

The valley leading up to Poças de São Bento is one of the most pronounced along this part of the river valley. The settlement site is located where the valley meets the gently undulating hinterland. Poças de São Bento may thus have been localized deliberately to mark the relation between the narrow lagoon and the inland. The mollusc shells may thus have had a deeper meaning than merely refuse. They marked a sense of affinity with the environment which, by virtue of its production, had a special meaning for human needs and conceptions. They may also have played a role as markers when the site was not being used. The combination of sooty sand and shell fragments marks out the area very distinctly. This marking may also have been developed into a mental meaning: a marking of the tamed sphere - the settlement site - in relation to the untamed surroundings. In a changeable world, there may have been various attempted ways to influence the forces of nature (Larsson 1995a). Accumulations of shells may thus have functioned as a metaphor for a desire to retain a status appropriate for the population.

With the existing C14 datings it is problematic to see an unambiguous chronological sequence between the find localities, especially in view of the fact that different kinds of organic material were analysed. Fig. 10A shows the results of the uncalibrated values, and fig. $10 \mathrm{~B}$ the calibrated values. One can possibly distinguish a certain relationship between the distance from the river delta and the age of the settlement site. The Atlantic transgression first affected the area closest to the lower parts of the river valley. The oldest is Arapouco, which is closest to the sea, and the youngest is Cabeço do Pez, furthest from the estuary (Fig. 1). The interval for the values from Poças de São Bento is at most just over 400 years, but they can also be interpreted as a difference that was no more than a couple of centuries. When seen in relation to the other two dated shell middens, the social system documented along this part of the River Sado existed for a relatively brief period.

Different settlement sites in the Sado area show a predominance of different forms of microlith. An explanation based on chronological differences seems the most probable. When no distinct chronological division can be discerned, a possible explanation for the differences is that the selection and composition were made to mark differences between different territorial groups.

\section{FROM MESOLITHIC TO NEOLITHIC}

Let us take a look forward in the development of society towards the introduction of agriculture and animal husbandry and simultaneous changes in social patterns, mortuary practices, and artefact composition.

C14 datings show that the Poças de São Bento site was used for just a few centuries, $7200-6700$ bp (6000-5600 B.C.). There are other shell middens in southern and central Portugal which show similar find material but which are a few centuries younger (Roche 1972; Kalb 1981; Arnaud 1986, 1989, 1990; Straus 1991; Zilhão 1992). There is thus no great change in the composition or forms of tools. This is particularly interesting from an Iberian perspective. While the 
traditional hunter-gatherer society was still using the rich lagoon biotopes, a new cultural complex arose simultaneously, designated as Cardial. This has new forms of artefacts, such as stone axes and clay pots (Arnaud 1982, 1990; Zvelebil \& Rowley-Conwy 1986; Straus 1991; Zilhão 1992). The ornamentation that occurs on the pots was often formed by impressions from the wavy edge of cockle shells (Cardium), hence the name of the culture. This is not merely a question of a new artefact composition, but also of the introduction of new elements in the economy, in the form of animal husbandry and possibly also tillage.

In some of the shell middens along the River Sado there are finds from the Cardial culture. In the topmost, non-shell-bearing layers at Poças de São Bento the culture is also represented in the form of Cardial ware and polished stone axes, but in contexts with a seemingly unchanged microlith composition. This suggests a merger of traditional features and new ideas. Judging by the radiometric datings, the difference in time between the Mesolithic settlement and the associated Cardial was relatively brief, or else the Cardial arose in certain coastal and inland regions while certain shell middens with a traditional culture were still occupied (Fig. 10). The fact that there were no accumulations of shells in the layer at Poças de São Bento where Cardial was documented may be due to poorer preservation conditions, but it is more likely that there was a change in the environment which meant that the supply of molluses declined or came to an end.

With a regression in sea level, the productive environment between salt water and fresh water supply was shifted further down the valley. The conditions necessary to bear settlement in this part of the Sado valley thus disappeared.

The deeper layers at Poças de São Bento, however, do not completely lack artefacts which can be interpreted as examples of a cultural environment in change. The beads of burnt clay may be one such example (Fig. 9:17-18). Another is some finds of broad trapezes (Fig. 9:9-10). This form of artefact is common among the oldest remains of the Iberian megalithic graves. However, C14 datings of these do not give any value higher than 5500 bp (Kalb 1981). The building phase of some megalithic graves probably came a few centuries earlier. The question is, however, how early? With the exception of some settlements, chiefly in caves, we lack knowledge of settlement in the inland in an early part of the Neolithic. In the discussion about the introduction of a new economy, combined with new mortuary practices, reflecting a changed social system, the youngest evidence of a hunter-gatherer society in a lagoon environment becomes so much more interesting.

The interest in the problem complex involving both the Late Mesolithic and the Neolithic has led to participation in a joint project in which the intention is to study a geographically limited megalithic area Vale de Rodrigo - located about $15 \mathrm{~km}$ southwest of Evora in the north of Alentejo Province. The investigation here has been going on for five seasons, 1990-95, with the Swedish contribution comprising the excavation of a large megalithic tomb (Larsson 1995b).

\section{ACKNOWLEDGEMENTS}

The investigations were conducted in collaboration with Dr José Morais Arnaud, Lisbon University. I wish to express my thanks to him for his assistance, and to thank the Swedish and Portuguese students who participated in the excavations. The charcoal analysis was carried out by Dr Thomas Bartholin, Laboratory of Quaternary Geology, Lund; the mammal bones were analysed by Dr Peter Rowley-Conwy, Department of Archaeology, Durham; fishbones were analysed by Professor Johannes Lepiksaar, Västra Frölunda and the analysis of flotation finds was carried out by Dr Roger Engelmark, Department of Archaeo- 
logy, Umeå. I wish to express my thanks to all of them for their work. The investigation was funded by the Swedish Council for Research in the $\mathrm{Hu}$ -

\section{REFERENCES}

Albrethsen, S. E. \& Brinch Petersen, E. 1977. Excavation of a Mesolithic cemetery at Vedbæk, Denmark. Acta Archaeologica 47, 1-28.

Andersen, S. H. 1991. Bjørnsholm. A Stratified K $\varnothing$ kkenmødding on the Central Limfjord, North Jutland. Journal of Danish Archaeology vol. 10 (1991), 59-96.

Andersen, S. H. \& Johansen, E. 1987. Ertebølle Revisited. Journal of Danish Archaeology vol. 5 (1986), 31-61.

Arnaud, J. M. 1982. La néolithique ancien et le processus de néolithisation au Portugal. Le Néolithique Ancien Mediterranéen. Actes du Colloque International de Préhistoire Montpellier 1981. Montpellier, 29-48.

- 1986. Post-glacial adaptations in southern Portugal. Paper presented at the World Archaeological Congress, Southampton.

- 1989. The Mesolithic Communities of the Sado Valley, Portugal, in their Ecological Setting. Bonsall, C. (ed.), The Mesolithic in Europe. Papers presented at the Third International Symposium, Edinburgh 1985. Edinburgh, 614-631.

- 1990. Le substrat mésolithique et le processus de néolithisation dans le sud du Portugal. Cahen, D. \& Otte, M. (éds) Rubane et Cardial. Actes de Colloque de Liège, novembre 1988. Etudes et Recherches Archéologiques de 1 'Université de Liège, no. 39, 437-446.

Brinch Petersen, E. 1988. Ein mesolithisches Grab mit acht Personen von Strøby Egede, Seeland. Archäologisches Korrespondenzblatt 18, Heft 2, 121-125.

Bruce-Chwatt, L. J. \& de Zulueta, M. D. 1980. The Rise and Fall of Malaria in Europe. A historicoepidemiological study. Oxford.

Chapman, R. 1981. The emergence of formal disposal areas and the 'problem' of megalithic tombs in prehistoric Europe. Chapman, R., Kinnes, I. \& Randsborg, K. (ed.), The archaeology of death. Cambridge, 71-81. manities and Social Sciences.

Translation by Alan Crozier.

Gonzalez Morales, M. R. \& Morais Arnaud, J. E. 1990. Recent Research on the Mesolithic in the Iberian Peninsula: Problems and Perspectives. Vermeersch, P. M. \& Van Peer, P. (ed.), Contributions to the Mesolithic in Europe. Leuven, 451-461.

Hodder, I. 1990. The Domestication of Europe. Structure and Contingency in Neolithic Societies. Oxford.

Hougaard Rasmussen, G. 1990. Okkergrave fra ældre stenalder på Djursland. Kuml 1988-89, 31-41.

Kalb, P. 1981. Zur relativen Chronologie portugiesischer Megalitgräber. Madrider Mitteilungen 22, 55-77.

Knutsson, H. 1995. Slutvandrat? Aspekter på övergången från rörlig till bofast tillvaro. Aun 20.

Larsson, L. 1984. The Skateholm Project. A Late Mesolithic Settlement and Cemetery Complex at a South Swedish Bay. Papers of the Archaeological Institute University of Lund 1983-1984, 5-38

- 1988. The Skateholm Project. Late Mesolithic Settlement at a South Swedish Lagoon. Larsson, L. (ed.), The Skateholm Project. I. Man and environment. Lund, 9-19.

- 1989a. Big Dog and Poor Man. Mortuary Practices in Mesolithic Societies of Southern Sweden. Larsson, T. B. \& Lundmark, H. (ed.), Approaches to Swedish Prehistory. A spectrum of problems and perspectives in contemporary research. Oxford, 211-223.

- 1989b. Ethnicity and traditions in Mesolithic mortuary practices of southern Scandinavia. Shennan, S. J. (ed.), Archaeological Approaches to Cultural Identity. London, 210-218.

- 1990. The Mesolithic of Southern Scandinavia. Journal of World Prehistory Vol. 4, No. 3, 257-309.

- 1993. Kitchen Middens. A Familiar Archaeological Site in a New Light. In: Arwidsson, G. 
et al. (eds.) Sources and Resources. Studies in Honour of Birgit Arrhenius. PACT 38. Rixensart, 267-285.

- 1995a. Man and Sea in Southern Scandinavia during the Late Mesolithic. Role of cemeteries in the view of society. In: Fischer, A. (ed.) Man and Sea in the Mesolithic. København. In press.

- 1995b. Stenar som förenar, stenar som betvingar. Vale de Rodrigo - en megalitbygd i södra Portugal. Vetenskapssocietetens i Lund Årsbok 1993, 5-31.

Lubell, D., Jackes \& Meiklejohn, C. 1989. Archaeology and Human Biology of the Mesolithic-Neolithic Transition in southern Portugal: a Preliminary Report. Bonsall, C. (ed.), The Mesolithic in Europe. Papers presented at the Third International Symposium, Edinburgh 1985. Edinburgh, 632-640.

Mateus, J. E. 1985. The coastal lagoon region near Calvalhal during the Holocene; some geomorphological aspects derived from a palaeoecological study at Lagoa Travessa. Actas II, Reunião do Quatemario Ibérico. Lisbon, 237249.

- 1992. Holocene and present-day ecosystems of the Carvalhal Region, Southwest Portugal. Lisboa.

Pequart, M. \& Pequart, S.-J. 1954. Hoëdic. Deuxième station-nécropole du mésolithique côtier Armoricain. Anvers.

Pequart, M., Pequart, S.-J., Boule, M. \& Vallois, H.
1937. Téviec. Station-nécropole mésolithique du Morbihan. Archives de I'Institut de Paleontologie Humaine Mémoire 18.

Price, D. T. 1985. Affluent Foragers of Mesolithic Southern Scandinavia. Price, D. T. \& Brown, J. A. (ed.), Prehistoric Hunter-Gatherers. The Emergence of Cultural Complexity. New York, 341-363.

Roche, J. 1972. Le gisement mésolithique de Moita do Sebastião. Muge. Portugal. I. Archéologie. Lisboa.

- 1989. Spatial Organization in the Mesolithic Sites of Muge, Portugal. Bonsall, C. (ed.), The Mesolithic in Europe: Proceedings of the Third International Symposium, Edinburgh 1985. Edinburgh, 607-613

Straus, L. G. 1991. The 'Mesolithic-Neolithic transition' in Portugal: a view from Vidigal. Antiquity 65, No. 249, 899-903.

Whittle, A. 1985. Neolithic Europe. A Survey. Cambridge.

Zilhão, J. 1992. Gruta do Caldeirão O Neolitico Antigo. Trabalhos de Arqueologia 6. Lisboa.

- 1993. The Spread of Agro-Pastoral Economies across Mediterranean Europe: A View from the Far West. Journal of Mediterranean Archaeology 6:1, 5-63.

Zvelebil, M. \& Rowley-Conwy, P. 1986. Foragers and farmers in Atlantic Europe. Zvelebil, M. (ed.), Hunters in transition. Mesolithic societies of temperate Eurasia and their transition to farming. Cambridge, 67-93. 
